\title{
The 1986 Lake Nyos Gas Disaster in Cameroon, West Africa
}

\author{
George W. Kling, Michael A. Clark, Harry R. Compton, Joseph D. Devine, \\ William C. Evans, Alan M. Humphrey, EdWard J. Koenigsberg, \\ John P. Lockwood, Michele L. Tuttle, Glen N. WAgner
}

\begin{abstract}
The sudden, catastrophic release of gas from Lake Nyos on 21 August 1986 caused the deaths of at least 1700 people in the northwest area of Cameroon, West Africa. Chemical, isotopic, geologic, and medical evidence support the hypotheses that (i) the bulk of gas released was carbon dioxide that had been stored in the lake's hypolimnion, (ii) the victims exposed to the gas cloud died of carbon dioxide asphyxiation, (iii) the carbon dioxide was derived from magmatic sources, and (iv) there was no significant, direct volcanic activity involved. The limnological nature of the gas release suggests that hazardous lakes may be identified and monitored and that the danger of future incidents can be reduced.
\end{abstract}

$\mathrm{F}$ OR THE SECOND TIME IN 2 YEARS THE COUNTRY OF Cameroon has been struck by an unusual natural disaster involving the release of lethal gas from crater lakes. The first of these events occurred on 15 August 1984 at Lake Monoun, and it caused the deaths of 37 people $(1)$. The second event on 21 August 1986 was much more devastating. The lethal gas released from Lake Nyos spread for distances up to $10 \mathrm{~km}$ from the lake and killed about 1700 people and 3000 cattle (Figs. 1 and 2). To our knowledge, these are the only recorded events in which gas released from lakes has caused the loss of human life. We describe here the results of a field investigation of Lake Nyos that began on 27 August 1986 and involved studies of the surrounding area and nearby lakes and springs.

On 21 August at about 2130 a series of rumbling sounds lasting perhaps 15 to 20 seconds caused people in the immediate area of the lake to come out of their homes. One observer reported hearing a bubbling sound, and after walking to a vantage point he saw a white cloud rise from the lake and a large water surge. Many people smelled the odor of rotten eggs or gunpowder, experienced a warm sensation, and rapidly lost consciousness. Survivors of the incident, who awakened from 6 to 36 hours later, felt weak and confused. Many found that their oil lamps had gone out, although they still contained oil, and that their animals and family members were dead. The bird, insect, and small mammal populations in the area were not seen for at least 48 hours after the event. The plant life was essentially unaffected.

On the morning of 22 August, people from the surrounding area started the grim task of recovery and burial. It was not until the morning of 24 August, after two Swiss missionary helicopter (Helimission) pilots flew into the area, that the "outside world" heard of the incident. At this time the lake surface was calm, but it was littered with floating mats of vegetation and had turned from its normal clear blue color to a rusty red. Vegetation damage showed that a water surge had washed up the southern shore to a height of $\sim 25 \mathrm{~m}$. A water surge $6 \mathrm{~m}$ high had flowed over the spillway at the northern end of the lake, and a fountain of water or froth had splashed over an 80-m-high rock promontory on the southwestern shore.

\section{Geology}

General geology. A number of small, young basaltic volcanoes have formed cinder cones and lava flows in northwestern Cameroon along part of the "Cameroon Volcanic Line," a northeast-southwest trending zone of crustal weakness that extends $1600 \mathrm{~km}$ from islands in the Atlantic Ocean into northwestern Cameroon and northeastern Nigeria (2). Volcanic explosions have also formed numerous circular maars, many of which are now occupied by deep crater lakes.

The Lake Nyos maar is formed in a coarse-grained biotite-quartz monzonite terrain of uncertain, pre-Tertiary age. This granitic terrain is cut by prominent faults, which are marked by pronounced lineaments, including the Nyos Valley north of Lake Nyos. Lake Nyos is one of three eruptive features in the immediate area; prominent basaltic cinder cones are located $1 \mathrm{~km}$ to the northeast and $2 \mathrm{~km}$ to the south (Fig. 2). Although the Lake Nyos crater may be the oldest of these eruptive features, it is still very young. Judging by the unweathered and little-eroded ash deposits on its flanks, it may be only a few hundred years old. The lake is $1925 \mathrm{~m}$ at its maximum length and $1180 \mathrm{~m}$ at its maximum width. It is shallow at the southern end but drops off steeply to a large, flat plain at a depth of $208 \mathrm{~m} \mathrm{(3)}$. This plain is formed of silt and mud of unknown thickness. Analysis of one sediment sample from the bottom indicated the presence of feldspar, quartz, biotite, and kaolinite; no fresh volcanic constituents were detected.

About two-thirds of the Lake Nyos crater is rimmed by quartz monzonite and the rest by ash that was erupted mainly at the time of crater formation. These products consist principally of pyroclastic surge deposits. The irregularly bedded deposits are up to $30 \mathrm{~m}$ thick

G. W. Kling is in the Department of Zoology, Duke University, Durham, NC 27706; M. A. Clark and G. N. Wagner are at the Armed Forces Institute of Pathology, Washington, DC 20306; H. R. Compton and A. M. Humphrey are with the U.S. Environmental Protection Agency, Edison, NJ 08837; J. D. Devine is in the Department of Geological Sciences, Brown University, Providence, RI 02912; W. C. Evans, J. P. Lockwood, and M. L. Tuttle are with the U.S. Geological Survey at, respectively, Menlo Park, CA 94025, Hawaiian Volcano Observatory, Hilo, HI 96718, and Federa Center, Denver, CO 80225; and E. J. Koenigsberg is at the U.S. Office of Foreign Disaster Assistance, Washington, DC 20523. 
at the crater rim, but they thin very rapidly and become finer grained away from the crater. Maximum clast size increases upward in the deposit, suggesting that increased violence occurred later in the crater-forming event. Ultramafic xenoliths are common in the upper third of the surge deposits and are up to $25 \mathrm{~cm}$ in diameter. These xenoliths, carried to the surface from great depths, are comprised mostly of the minerals olivine, orthopyroxene, clinopyroxene, and spinel. They contain abundant fluid inclusions of $\mathrm{CO}_{2}$ and $\mathrm{H}_{2} \mathrm{O}$. Many of the ultramafic clasts are mantled by olivine-plagioclase basalt, and angular basalt clasts are common throughout the surge deposits. The ash beds are moderately well-consolidated near the crater rim, but are poorly consolidated and easily erodible on the flanks. They form vertical cliffs along the northeast rim and are sufficiently durable to form the resistant bed of the stream that drains Lake Nyos to the northwest. This stream plunges over a 35to 40-m-high waterfall after descending a few meters below lake level, leaving a 40-m-wide septa or spillway to bound Lake Nyos to the north. The thickness of ash underlying the structurally weak spillway is unknown. Pyroclastic surge deposits were originally deposited around the entire circumference of the lake, but they are now exposed discontinuously around the lake's southern end. The location of these deposits suggests that they may have been eroded away by waves generated by previous gas events.

Origin and subsurface structure of Lake Nyos. The formation of the present Lake Nyos crater was preceded by a short period of relatively quiescent eruptive activity, as indicated by the fire-fountain agglomerate and a thin basalt flow exposed beneath pyroclastic ash beds on the northeast shore of the lake. The volume of the ejected pyroclastic material is considerably less than the volume of the present maar crater, indicating that the crater was formed in part by collapse of adjoining rocks.

The Lake Nyos maar is undoubtedly underlain by a diatreme. The diatreme was formed above a dike of ascending, volatile-rich basaltic magma, whose source lay within the earth's mantle as evidenced by the abundant ultramafic xenoliths present. This rising basaltic magma explosively fragmented as it neared the earth's surface, either by release of dissolved magmatic volatiles or by contact with meteoric water.

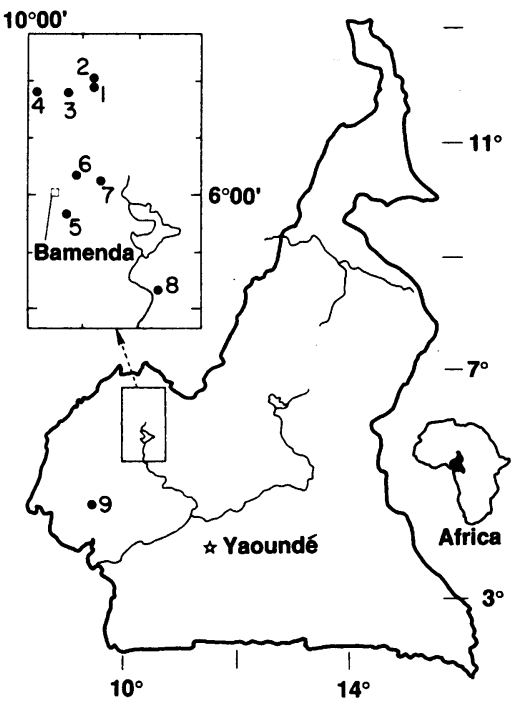

Fig. 1. Location of Cameroon and northwestern lakes. Labeled sites: 1, Lake Nyos; 2, Nyos spring; 3, Lake Nyi; 4, Lake Wum; 5, Lake Bambuluwe; 6, Luih spring; 7, Gesel spring; 8, Lake Monoun; and 9, Barombi Mbo.
Fig. 2. Photoreconnaissance geologic sketch map of Lake Nyos. Abbreviations: Qal, alluvium; Qvs $_{1}$, basaltic scoria southeast of Lake Nyos; $\mathrm{Qvf}_{1}$, basaltic flow southeast of Lake Nyos; $\mathbf{Q v f}{ }_{2}$, basaltic flow southeast of Lake Nyos (source south of map edge); Qvs 3 , basaltic scoria northeast of Lake Nyos; Qvf Lake Nyos; Qps, phreatomagmatic pyroclastic surge deposits surrounding Lake Nyos; $\mathrm{Qv}_{\mathbf{4}}$, basaltic scoria and flow along northeast shore of Lake Nyos; and qm, coarse-grained biotite quartz monzonite of pre-Tertiary age (overlain by lateritic soil).

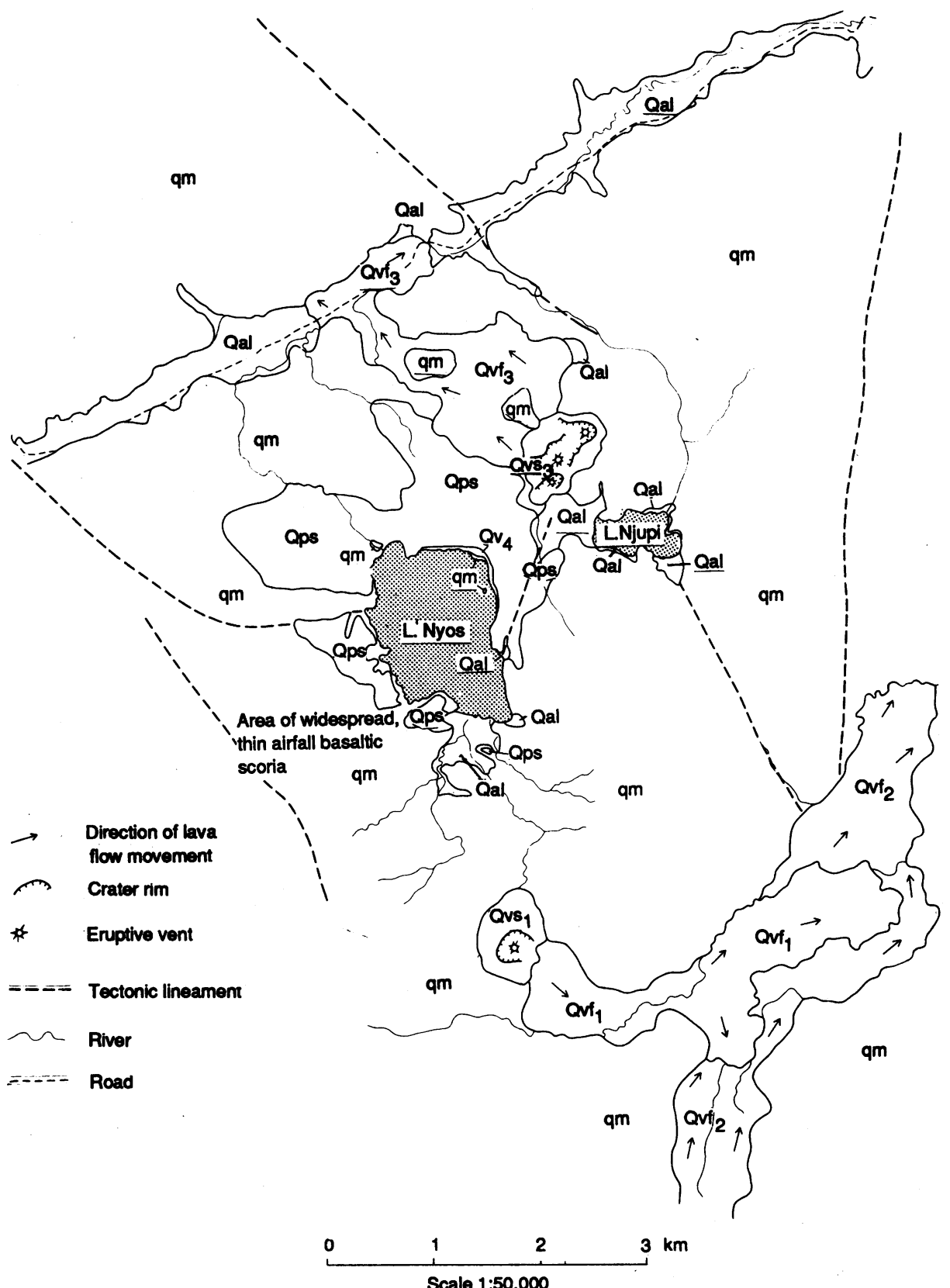

SCIENCE, VJL. 236 


\section{Gas Origin}

Three possible sources for the gas released on 21 August are volcanic, magmatic, or biogenic. As the terms are used in this article, volcanic gas is associated with high-temperature, eruptive processes; magmatic gas is released from magma below the earth's surface, is relatively cool when it reaches the surface, and has lost its reactive constituents such as sulfur and chlorine compounds and carbon monoxide; biogenic gas is produced by decomposition of organic matter. Our data suggest that the bulk of the gas released from this event was at low temperature and of magmatic origin.

Carbon diaxide in Cameroon magmas. On the basis of geophysical and geochemical evidence, it has been inferred that the mantle source region of basaltic Cameroon magmas lies at depths greater than about $90 \mathrm{~km}(4,5)$. In addition, the isotopic and trace-element geochemistry of Cameroon magmas suggests that they are derived from parent melts produced by very small degrees of partial melting of the mantle. These critical observations explain why Cameroon magmas tend to be rich in $\mathrm{CO}_{2}$.

The source region for these magmas is at pressures great enough to stabilize carbon as the carbonate mineral dolomite (6). Small degrees of partial melting of the mantle result in breakdown of the carbonate mineral and solution of $\mathrm{CO}_{2}$ in the melt. Melt ascending toward the surface exsolves $\mathrm{CO}_{2}$ as pressure drops, and it will begin to degas $\mathrm{CO}_{2}$ at depths between 80 and $100 \mathrm{~km}(6)$. Crystallization of cooling magma during ascent or storage within the crust causes further release of $\mathrm{CO}_{2}$ and other volatiles from the residual melt. For example, magma that was implaced in the conduit during the formation of Lake Nyos may still be a source of $\mathrm{CO}_{2}$. Bubbles of exsolved magmatic volatiles ascend through the melt and along grain boundaries and fractures in overlying crustal rocks. In the normal course of events, such gases ultimately escape to the atmosphere and dissipate safely. If, however, access channels to the atmosphere are blocked by water or surface deposits, the gases may accumulate at shallow depths and pose hazards. In Cameroon, potential accumulation sites include near-surface voids within diatremes, ground water, and stratified crater lakes. Thus, geological conditions in Cameroon are favorable for the generation and accumulation of $\mathrm{CO}_{2}$-rich gas in areas such as Lake Nyos.

Distinctions between possible gas sources. Temperature profiles of

Table 1. Gas concentrations in percentage by volume. Values of isotopes in per mil. The $\delta^{13} \mathrm{C}-\mathrm{HCO}_{3}$ is measured on all of the $\mathrm{CO}_{2}$ species present. The Lake Nyos sample taken on 3 September 1986 from $200 \mathrm{~m}$ is representative of samples at 103 and $155 \mathrm{~m}$. The Usu volcano data are from Matsuo et al. (11). Hydrocarbons from $C_{2}$ to $C_{4}$ were detected in the range from 10 to $100 \mathrm{ppb}$ in Lake Nyos samples.

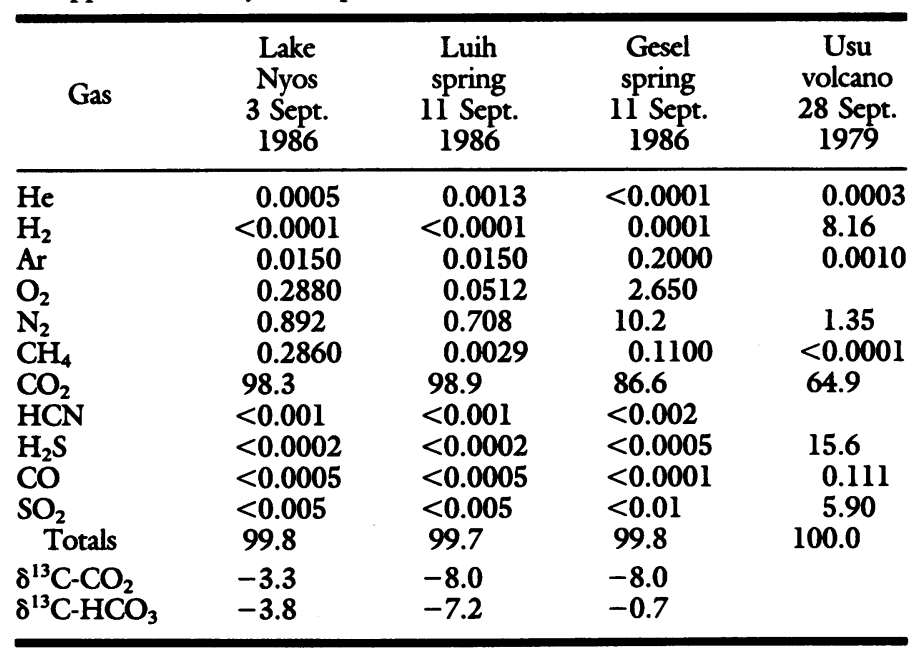

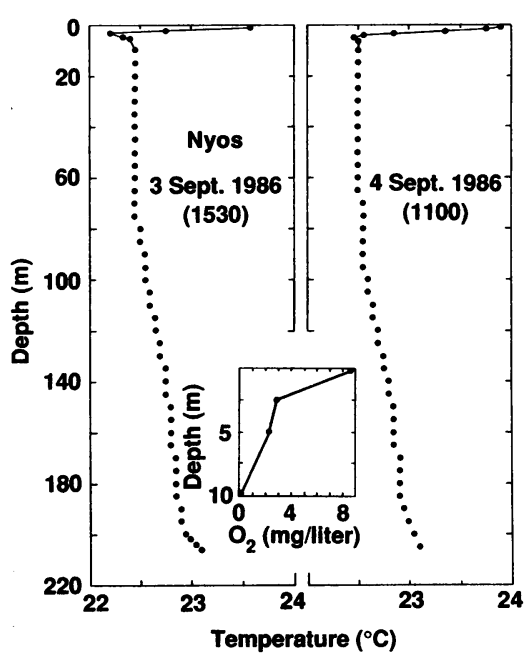

Fig. 3. Plots of oxygen concentration (4 September sampling) and temperature for Lake Nyos.

Lake Nyos taken on 4 and 5 Seprember indicate that the water was relatively cool and nearly isothermal after the event (Fig. 3). The bottom temperatures in Lake Nyos were no higher than those in other tropical lakes at similar elevation and latitude (7). We could not substantiate a report by a few local villagers that hot water was present in the Lake Nyos outflow stream near Nyos village.

A volcanic injection of magma or of gas from a phreatic explosion would have been accompanied by an input of heat and an increase of water temperature. For example, during volcanic injection of lava and gas into the Soufrière crater lake (St. Vincent), water temperatures reached $82^{\circ} \mathrm{C}(8)$. On the basis of maximum cooling rates in tropical lakes $(9)$, Lake Nyos could have dissipated enough heat in the 12 days before our sampling to decrease the temperature at any depth throughout the water column by only $0.5^{\circ} \mathrm{C}$. The supposition of a significant heat input thus becomes untenable.

Only the top $10 \mathrm{~m}$ of Lake Nyos contained measurable dissolved oxygen (Fig. 3). Precipitation of ferric hydroxide in the oxygenated surface waters caused the lake's reddish-brown color; below $10 \mathrm{~m}$ the water was clear. Composition of the bottom water before the event is unknown. The most noticeable change in surface water chemistry after the event was an increase in the concentration of most species of chemicals (Fig. 4). These concentrations showed a definite increase with depth, implying either chemical stratification before the event or, less likely, incomplete mixing of a recent chemical input near the bottom.

A substantial input of lava or volcanic gas into the lake would add sulfur and chlorine compounds. An example of this is found in Soufrière crater lake, where large increases in the concentrations of sulfur and chlorine compounds accompanied volcanic injection (8). Lake Nyos, however, showed no such enrichment of sulfur and chlorine compounds in either lake waters or sediments (10). Hydrogen fluoride is also a common volcanic gas (Table 1) (11), but fluoride was nearly absent from the waters of Lake Nyos.

On the basis of our August field sampling, we estimated that 1 liter of hypolimnetic water in Lake Nyos contained 1 to 5 liters of dissolved gas. Carbon dioxide made up 98 to $99 \%$ of this gas (Table 1). The nonvolcanic character of the gas is most apparent in the low concentrations of carbon monoxide, hydrogen, hydrogen sulfide, and sulfur dioxide compared to those in volcanic gas. Studies of volcanic emanations from magmas similar in composition to those erupted in Cameroon, notably those from Iceland and Hawaii, show that the weight ratio of $\mathrm{CO}_{2}$ to sulfur in near-surface volcanic gases is typically less than $100(12,13)$. In contrast, the ratio of $\mathrm{CO}_{2}$ to sulfur in Lake Nyos bottom waters is greater than $10^{4}$.

Sudden release of a large reservoir of gas stored below the lake 


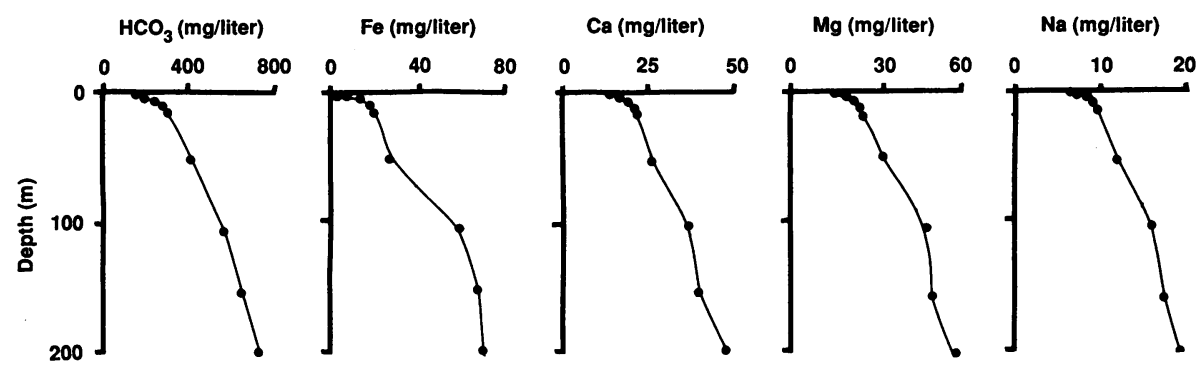

Fig. 4. Depth profiles of major ions in Lake Nyos. Analyses of Nyos surface waters collected on 8 May 1985 (36) indicate that the predominant anion was bicarbonate $(21 \mathrm{mg} /$ liter $)$ and no single cation concentration exceeded $2.3 \mathrm{mg} / \mathrm{liter}$.

sediments would likely disrupt lake bottom topography during its ascent through the sediments. A series of four depth-sounding profiles across the lake revealed no crater or disturbance on the lake bottom corresponding to a localized vent, although some discharge of gas through a subsurface, cliffside vent is possible. Any release of gas through the sediments would have also dispersed particles of fine sediment up into the water. No suspended sediment was detected in any water sample below $10 \mathrm{~m}$. Settling times of fine sediment would be very slow (14), and outflow rates in Lake Nyos were too small to account for removal of deep suspended sediment by flushing. The lack of evidence for bottom disruption and suspended sediment, in addition to the water temperature, composition of dissolved gases,

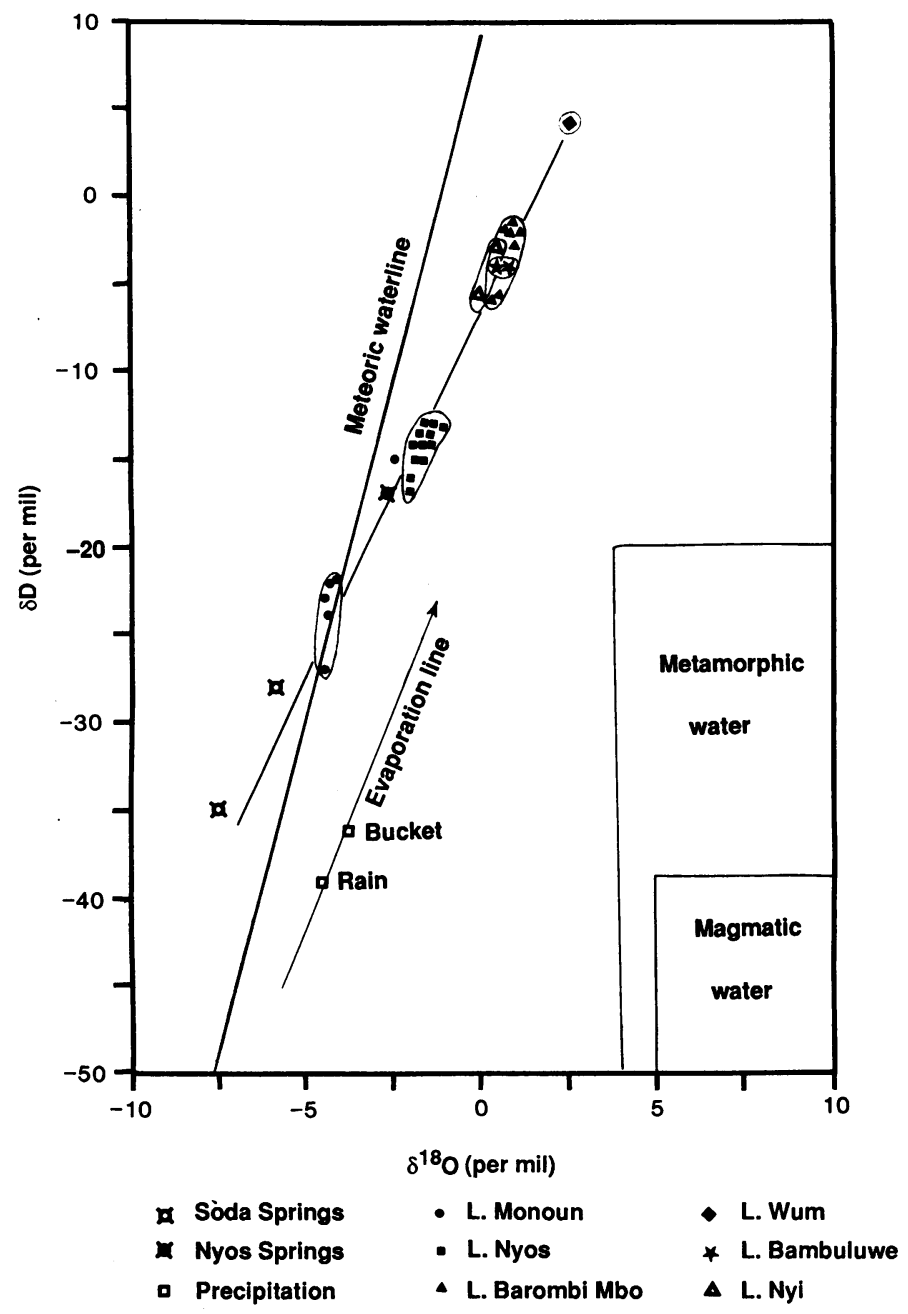

Fig. 5. Plot of $\delta \mathrm{D}$ versus $\delta^{18} \mathrm{O}$ for precipitation, lake water, and springs in Northwest Cameroon. The precipitation was collected during a rain storm at Lake Nyos. "Bucket" represents a precipitation sample integrated over 14 days, beginning on 21 August 1986. Also shown are the meteoric waterline (22) and the calculated fields of primary magmatic and metamorphic waters (23). and low sulfur content of lake waters and bottom sediments argues against a recent, direct injection of lava or volcanic gas into Lake Nyos.

With this evidence against a major volcanic injection, it becomes necessary to distinguish between seepage of magmatic or biogenic gas. Biogenic carbon is enriched with recently produced ${ }^{14} \mathrm{C}$ and therefore has a young age. Carbon in magmatic gas has an infinitely old apparent age. A preliminary ${ }^{14} \mathrm{C}$ date $(15)$ of $>35,000$ years before the present obtained from $\mathrm{CO}_{2}$ gas dissolved in Lake Nyos indicates no young, biogenic source. One could argue that this ${ }^{14} \mathrm{C}$ date reflects old organic carbon in the sediments or the water column. This argument would be difficult to support if, as geological evidence indicates, Lake Nyos is no more than several hundred years old. In addition, a ratio of ${ }^{3} \mathrm{He} /{ }^{4} \mathrm{He}$ greater than 1 demonstrates the presence of significant amounts of magmatic gas (16). The ${ }^{3} \mathrm{He} /{ }^{4} \mathrm{He}$ ratio of 6 in Lake Nyos bottom water (17) supports the conclusion that the gas is magmatic rather than biogenic.

The stable carbon isotope composition of $\mathrm{CO}_{2}$ and methane in lakes may also distinguish between biogenic and magmatic sources. The average values of $\delta^{13} \mathrm{C}$ in the $\mathrm{CO}_{2}$ and bicarbonate dissolved in Lake Nyos and in the two soda springs sampled ranged from -0.7 to $\mathbf{- 8 . 0}$ per mil (Table 1). These values are consistent with the hypothesis of a magmatic carbon source but cannot be used to definitely rule out a biogenic source because they fall in the range where biogenic and magmatic isotopic carbon values overlap. There appears to be some biogenic gas in Lake Nyos, although it is limited to very small amounts as evidenced by the helium and ${ }^{14} \mathrm{C}$ isotopes. The $\delta^{13} \mathrm{C}$ value of the methane, for instance, is similar to values found in other lakes that indicate production by a biogenic pathway $(18,19)$. Taken together, however, the ${ }^{14} \mathrm{C}, \mathrm{He}$, and $\delta^{13} \mathrm{C}$ data clearly indicate that most of the $\mathrm{CO}_{2}$ in Lake Nyos is of magmatic origin.

\section{Gas Accumulation}

Numerous soda springs in Cameroon contain high concentrations of dissolved $\mathrm{CO}_{2}(20)$ that biogenic processes alone could not produce. The major ion chemistry of Lake Nyos is similar to that found in a nearby soda spring (20). These waters are significantly enriched in magnesium compared to surrounding lakes and springs $(20,21)$, suggesting a similar origin for the Lake Nyos and spring water. Oxygen and hydrogen isotopes were examined to test the hypothesis that this common source provided a means by which dissolved $\mathrm{CO}_{2}$ entered the hypolimnion. The isotope data from our lake, spring, and rain samples show trends similar to those produced by evaporative concentration or by mixing of ground water and surface water (Fig. 5) $(22,23)$. If evaporative concentration is the only process affecting these waters, both $\delta{ }^{18} \mathrm{O}$ and $\delta \mathrm{D}$ values should increase with increasing ionic strength. The observed data show an inverse relation, however, and the intermediate values of Lakes Monoun and Nyos instead suggest a mixing of spring and lake components (Fig. 6). 
A necessary condition for the accumulation of dissolved $\mathrm{CO}_{2}$ in the lake is that deep water is not mixed to the surface. Stratification resulting from a large density difference between bottom and surface waters may persist for long periods of time, allowing solutes and dissolved gases to build up in the hypolimnion. The observed vertical distribution of solutes in Lake Nyos suggests that the lake was strongly stratified before the event (Fig. 4). Also, movement of dissolved iron from deep waters to the surface, where it combined with oxygen to form a reddish precipitate, indicates that some mixing of surface and bottom waters occurred during the gas release. The isotope data and the vertical distribution of solutes are thus consistent with the hypothesis that dissolved $\mathrm{CO}_{2}$ entered Lake Nyos in ground water and was stored in the hypolimnion.

\section{Release of Gas from the Lake}

The gas cloud was produced by the rapid exsolution of large amounts of $\mathrm{CO}_{2}$ from Lake Nyos. The burst of gas leaving the lake resulted in the formation of surface waves. Areal distribution of dead cattle indicated that the gas cloud initially filled the lake basin to a height $\sim 100 \mathrm{~m}$ above the crater rim. Because $\mathrm{CO}_{2}$ is denser than ambient air and because its density would have increased as it cooled upon expansion (24), the cloud tended to maintain its integrity as it spilled over the crater rim into low-lying areas. Flow of $\mathrm{CO}_{2}$ at lethal concentrations into topographically low areas has been well documented (25). The head of the flowing cloud probably maintained the highest concentrations of $\mathrm{CO}_{2}$ because it would have been continually recharged from the faster flowing tail (26). Because of imprecise accounts of the time of deaths, it was not possible to determine how fast the head of the cloud advanced down the river valleys. We can infer, however, that the flow would stretch out and slow down because of friction on the cloud from trees and other obstacles in the flow path (26). This flow, plus entrainment of less dense surrounding air, would result in dispersion and partial dissipation of gas behind the flow front and could create areas of significant concentrations of $\mathrm{CO}_{2}$ in topographic depressions, in areas of dense vegetation, and in enclosed spaces. These pockets could linger for long periods of time.

Volume of gas released. The hypothesis of gas storage in the hypolimnion requires that the amount of $\mathrm{CO}_{2}$ released could have been dissolved in the lake, and that the loss of $\mathrm{CO}_{2}$ from the lake could be accounted for by a lowering of water level. At full saturation, Lake Nyos could hold $1.5 \mathrm{~km}^{3}$ of $\mathrm{CO}_{2}$ (27). The bottom waters are still about $20 \%$ saturated with $\mathrm{CO}_{2}(28)$. By using this information and by assuming pre-event saturation, we conclude that the lake could have released about $1.2 \mathrm{~km}^{3}$ of $\mathrm{CO}_{2}$. Release of this volume of gas from solution would have caused the lake level to drop $\sim 110 \mathrm{~cm}$, which is in accord with the observations of Helimission pilots and local villagers.

When estimating the volume of $\mathrm{CO}_{2}$ needed to fill the affected area and account for all fatalities, we assumed that between Lake Nyos and the village of Nyos the cloud height tapered from 100 to $50 \mathrm{~m}$. The minimum volume estimate of a $100 \% \mathrm{CO}_{2}$ cloud that would fill the described area $\left(0.9 \mathrm{~km}^{3}\right)$ is less than our estimate of the maximum volume released during the event. The $0.9 \mathrm{~km}^{3}$-value is conservative considering that concentrations of $\mathrm{CO}_{2}$ above $10 \%$ are lethal to humans (29).

Trigger for the gas release. Given that a significant amount of gas was probably dissolved in the hypolimnion before the event, several mechanisms could have effected its release. These include an internal wave, a seismic shock, a landslide or heavy flood of water into the lake, or nearly any disturbance of this metastable system. During our study in late August we observed that water brought to the surface

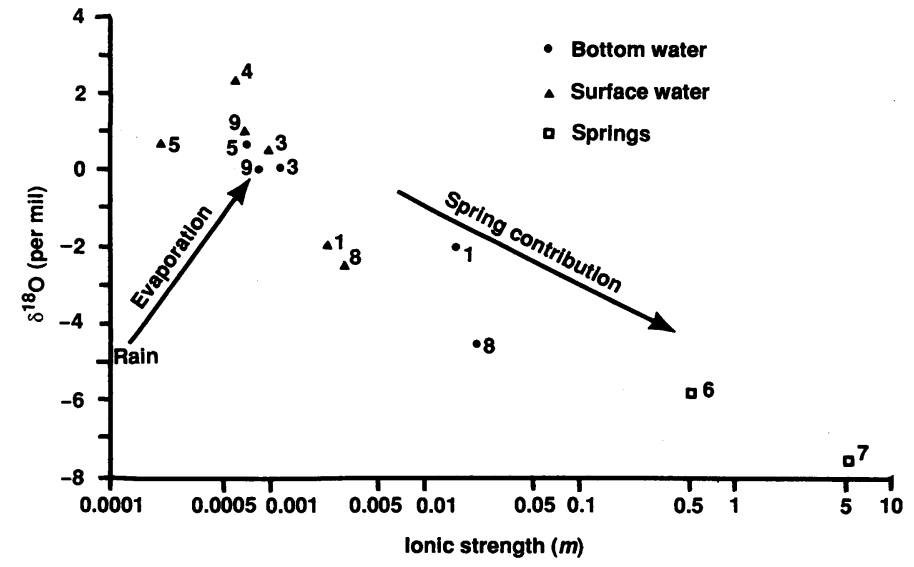

Fig. 6. Plot of $\delta^{18} \mathrm{O}$ versus ionic strength (site numbers as in Fig. 1). Plot of $\delta \mathrm{D}$ versus ionic strength shows an identical trend. Ionic strengths for Lake Monoun and the springs were calculated from data in $(I)$ and $(20)$, respectively.

from a depth of $5 \mathrm{~m}$ effervesced (30). This finding suggests that nucleation sites are not a limiting factor and that bubble formation is spontaneous upon pressure reduction under supersaturated conditions. As a parcel of water is moved toward the surface, the total ambient pressure decreases until supersaturation conditions are met and bubbles form. The distance moved to create this condition defines the critical amplitude of vertical water movement required to initiate degassing.

The gas release could have been triggered by any disturbance that vertically moved water a distance greater than the critical amplitude. As waters approach saturation with respect to $\mathrm{CO}_{2}$, the critical amplitude approaches zero, and extremely small vertical water movements could trigger degassing. Internal waves that occur at the boundary between two layers of water at different densities are common in lakes (31). It is not yet possible to estimate a likely internal wave amplitude in Lake Nyos just before the event because the fundamental fluid dynamics equations do not apply in a system where expanding gas is producing turbulence. Measuring the actual amplitude of internal water movements, however, and comparing them to the critical amplitude as calculated from the $\mathrm{CO}_{2}$ saturation would provide a means of monitoring the stability and potential danger of a lake.

Significant seismic activity during or preceding the event was not observed at the Kumba recording station $220 \mathrm{~km}$ southwest of Lake Nyos. Several large boulders perched on topographic high points around the lake and the neatly stacked household goods in many homes imply that the magnitude of any local shock was negligible. Anecdotal evidence from survivors also does not support the hypothesis of a seismic shock. A fresh landslide scar was present on the western cliffs of the lake, although we found no evidence of the timing of its occurrence or of anomalies in lake bottom sediment topography at the subsurface base of these cliffs.

\section{Pathology}

Testimonies of survivors indicate that the perceptions and effects of the gas cloud changed with distance from the lake. Survivors from the village of Nyos and other localities within $3 \mathrm{~km}$ of the lake described experiencing no unusual odor or taste before losing consciousness. They described fatigue, light-headedness, warmth, and confusion before collapsing and lying unconscious for up to 36 hours. In contrast, survivors on the outskirts of Nyos and in villages up to $10 \mathrm{~km}$ from the lake described awakening to an odor of rotten 
eggs or gunpowder. Like other survivors, they noted shortness of breath, dizziness, and confusion before losing consciousness. Most of these individuals had transitory respiratory complaints, but they continued to experience irritation of mucous membranes for several days. Upper extremity skin lesions were unilateral and usually over bony prominences; lesions on the torso or lower extremities showed a more even distribution. Few individuals had characteristic thermal burns; most cases of burns were related to collapse in or near a heat source. Many survivors attributed their skin lesions to gas exposure, but clinically these lesions were related to other disease processes that clearly antedated 21 August 1986. Several individuals experienced partial paralysis and loss of feeling, which in each case could be attributed to falls that caused fractures or dislocations, or to prolonged periods of unconsciousness in a fixed position. The airway passages showed no anatomical evidence of irritation associated with exposure to high levels of ammonia or nitric acid. Survivors also complained of nausea, vomiting, and diarrhea, all of which are known symptoms of $\mathrm{CO}_{2}$ poisoning (32). Differing reports regarding prodromal signs and symptoms in survivors are attributed to varying concentrations of $\mathrm{CO}_{2}$ for different periods of time.

Autopsies were performed on two adult males. Cause of death in the first victim, who survived for several days and then succumbed, was a multilobal bacterial pneumonia; he had no skin lesions. The other victim was examined on site after exhumation; the body showed moderate decomposition but no obvious anatomic cause of death. Toxicology studies on autopsy material from these victims and material collected by Cameroonian physicians from another male showed no elevation in carboxyhemoglobin saturations, cyanide concentrations, or sulfhemoglobins. Moderate increases in methemoglobin were attributed to decomposition. The human specimens showed small quantities of alcohol, although the absence of similar levels in animal specimens suggests that this finding represents antemortem alcohol ingestion rather than decomposition. No other drug substances were identified.

The Helimission pilots reported that the victims appeared to have "died in their tracks" without evidence of agonal struggle. They also described skin blisters, serosanguinous fluid flowing from the mouth and nostrils, and a bloated appearance of the faces. We confirmed these observations by studying the photographs and film, but they are believed to be typical findings of early postmortem decomposition.

Analysis of color print and color infrared photographs of the area surrounding Lake Nyos revealed no specific plant damage attributed to the gas cloud. In addition, $x$-ray photoelectron spectroscopy, scanning electron microscopy, and energy dispersive analysis by $\mathrm{x}$ ray detected no obvious differences in structural features or elemental composition between Lake Nyos plant samples and controls collected from distant locations (33).

These data support the conclusion that the toxic gas cloud was most likely composed of $\mathrm{CO}_{2}$ and that the victims died of $\mathrm{CO}_{2}$ asphyxiation. Survivability was not predicted on any existing epidemiological feature. If we exclude the thermal burns, skin lesions on the survivors appear to represent traumatic positional effects from the gas-induced prolonged unconsciousness. Similar traumatic lesions are described from drug-induced comas (34). High levels of $\mathrm{CO}_{2}$ are known to be irritating to mucous membranes and to produce a pungent olfactory sensation reminiscent of gunpowder or rotten eggs (35). This phenomenon is termed "olfactory hallucination" and may affect senses other than smell. For example, the feeling of warmth described by the survivors may be a sensory hallucination, considering that in one study $60 \%$ of subjects experienced sweating when exposed to an atmosphere containing $6 \% \mathrm{CO}_{2}$ (35).
Our analysis of findings similar to the descriptions of fatalities in the Lake Monoun event ( 1 ) leads us to believe that the lesions described at Lake Monoun were merely those of postmortem decomposition.

\section{Conclusions}

The geochemical and geophysical characteristics of Cameroon magmas together with expected geologic conditions in the Lake Nyos area explain the accumulation of $\mathrm{CO}_{2}$-rich gas. Water temperatures, composition of dissolved gases, undisturbed sediment, and the low sulfur content in this system are difficult to reconcile with a hypothesis of recent, direct injection of lava or of gas from a phreatic explosion. On the basis of the ${ }^{14} \mathrm{C}, \mathrm{He}$, and $\delta^{13} \mathrm{C}-\mathrm{CO}_{2}$ data from dissolved gas in the lake, almost all of the $\mathrm{CO}_{2}$ released was of magmatic origin.

The similarity in relative proportions of solutes in Lake Nyos and a nearby $\mathrm{CO}_{2}$-rich soda spring suggests a common origin for the spring and lake water. Oxygen and hydrogen isotope data substantiate this connection and support the hypothesis that $\mathrm{CO}_{2}$ entered the lake in a dissolved form in ground water. Stratification before the event is indicated by the present distribution of solutes. If persistent, this stratification would allow for accumulation of $\mathrm{CO}_{2}$ in the hypolimnion. If we assume that Lake Nyos was saturated before the event, it could have released about $1.2 \mathrm{~km}^{3}$ of $\mathrm{CO}_{2}$, an amount slightly greater than the minimum volume estimate of a $100 \% \mathrm{CO}_{2}$ cloud that would account for all fatalities. The trigger mechanism that released gas from the lake is unknown; if waters were nearly saturated before the event, any small disturbance of the water column would have initiated degassing.

Interviews with survivors and the pathologic studies indicated that victims rapidly lost consciousness and that death was caused by $\mathrm{CO}_{2}$ asphyxiation. At nonlethal levels, $\mathrm{CO}_{2}$ acts like an anesthetic and can produce sensory hallucinations, such that many people exposed to $\mathrm{CO}_{2}$ will report the odor of sulfur compounds when none are present. Skin lesions found on survivors represent pressure sores, and in a few cases exposure to a heat source, but there is no evidence of chemical burns or of flash burns from exposure to hot gases. All other findings on the deceased victims can be attributed to postmortem decomposition.

High concentrations of $\mathrm{CO}_{2}$ remain dissolved in Lake Nyos and represent a potential hazard until they can be safely lowered. The possibility of a failure of the weak natural dam at the Lake Nyos outlet poses an additional hazard. It will be necessary to monitor gas concentrations in this and other lakes to determine the potential of future releases of gas stored in lakes. Remediation of such natural hazards is feasible by controlled pumping of gas-rich hypolimnetic waters to the surface.

\section{REFERENCES AND NOTES}

1. H. Sigurdsson et al., J. Volcanol. Geotherm. Res. 31, 1 (1987).

2. J. G. Fitton, Earth Planet. Sci. Lett. 51, 131 (1980).

3. The volume of Lake Nyos is $1.76 \times 10^{8} \mathrm{~m}^{3}$, and the mean depth is $112 \mathrm{~m}$

4. F. Gumper and P. W. Pomeroy, Bull. Seimol. Soc. Am. 60,651 (1970).

5. J. G. Fitton and H. M. Dunlop, Earth Planet. Sci. Lett. 72, 23 (1985).

6. P. J. Wyllie, in Proceedings of the 2 nd International Kimberlite Conference, F. R. Boyd and H. A. Meyer, Eds. (American Geophysical Union, Washington, DC, 1979), vol. 1, pp. 319-329.

7. W. M. Lewis, Jr., Limnol. Oceanogr. 18, 200 (1973).

8. H. Sigurdsson, J. Volcanol. Geotherm. Res. 2, 165 (1977).

9. R. B. Wood, M. V. Prosser, R. M. Baxter, Freshwater Biol. 6, 519 (1976).

10. The waters of Lake Nyos contained $<0.20 \mathrm{mg} /$ liter of $\mathrm{SO}_{4}{ }^{2-},<0.80 \mathrm{mg} /$ liter of $\mathrm{Cl}^{-}$, and $<0.01 \mathrm{mg} /$ liter of $\mathrm{F}^{-}$. Sediments contained $0.11 \%$ by weight of total sulfur.

11. S. Matsuo, J. Ossaka, J. Hirabayashi, T. Ozawa, K. Kimishima, Bull. Volcanol. 45, 261 (1982). Matsuo et al. report $2.97 \% \mathrm{HCl}$ and $1.02 \% \mathrm{HF}$.

12. T. M. Gerlach, J. Geophys. Res. 91, 12177 (1986).

13. S. Amorsson, ibid., p. 12261.

14. According to Stokes law, a clay particle would settle $2 \mathrm{~m}$ per day in the absence of turbulence. 
15. S. Robinson, abstract, Spring 1987 American Geophysical Union National Meeting.

16. P. J. Hooker, R. Bertrami, S. Lombardi, R. K. O'Nions, E. R. Oxburgh, Geochim. Cosmochim. Acta 49, 2505 (1985).

17. B. M. Kennedy, abstract, Spring 1987 American Geophysical Union National Meeting. Our minimum estimate of ${ }^{3} \mathrm{He}$ concentration of $2.9 \times 10^{-7} \mu M$ in the lake is much greater than any possible enrichment from tritium decay.

18. M. J. Whiticar, E. Faber, M. Schoell, Geochim. Cosmochim. Acta 50, 693 (1986).

19. W. G. Deuser, E. T. Degens, G. R. Harvey, M. Rubin, Science 181, 51 (1973).

20. A. Marechal, Geologie et Geochimie des Sources Thermominerales du Cameroon [Office de la Recherche Scientifique et Technique d'Outre-Mer (ORSTOM), Paris, 1976].

21. Concentrations of $\mathrm{Mg}^{2+}$ in Lake Nyos (16 to $57 \mathrm{mg} /$ liter) (Fig. 4) are greater than those in any other lake sampled ( $<4.2 \mathrm{mg} /$ /iter). Concentrations in Nyos spring were $146 \mathrm{mg} /$ liter, whereas those in Luih and Gesel springs were 40 and $21 \mathrm{mg}$ liter, respectively $(20)$.

22. H. Craig, Science 133, 1702 (1961).

23. H. P. Taylor, Jr., in Geochemistry of Hydrothermal Oil Deposits, H. L. Barnes, Ed. (Wiley, New York, 1979), pp. 236-277.

24. The exact density of the $\mathrm{CO}_{2}$ cloud would depend on its temperature. Isenthalpic decompression of $\mathrm{CO}_{2}$ exsolved at $2 \mathrm{latm}$ (pressure at lake bottom) and brought to $1 \mathrm{~atm}$ would cause a $33^{\circ} \mathrm{C}$ cooling of the gas. Isentropic decompression would result in greater cooling; about $10 \%$ of the gas would freeze to form dry ice. If bottom water and gas rise together adiabatically, the mixture would cool by $3^{\circ}$ to $5^{\circ} \mathrm{C}$ because of the heat of exsolution and decompression of $\mathrm{CO}_{2}$. In either case, sufficient expansion work can be done by the gas to account for water surges and the $80-\mathrm{m}$ water fountain that accompanied the event.

25. F. LeGuern, H. Tazieff, R. Faivre Pierret, Bull. Volcanol. 45, 153 (1982).

26. J. E. Simpson, J. Fluid Mech. 14, 213 (1982).
27. Volume of gas is reported at standard temperature and pressure and calculated by using relationships in R. F. Weiss [Mar. Chem. 2, 203 (1974)].

28. Values of $p \mathrm{CO}_{2}$ are based on a 22 January 1987 sampling at $200 \mathrm{~m}$ with pressurized containers.

29. G. R. Sharp, in Aviation Medicine: Physiology and Human Factors, G. Dhenin, Ed. (Tri-med Books, London, 1972), pp. 202-203.

30. Lake Monoun water was also observed to effervesce when brought to the surface from a depth of $2.5 \mathrm{~m}$ (G. W. Kling, unpublished data, May 1985)

31. C. H. Mortimer, Mitt. Int. Ver. Theor. Angew. Limnol. 20, 124 (1974).

32. W. F. von Oettingen, Poisoning: $A$ Guide to Clinical Diagnosis and Treatment (Savelers, Philadelphia, 1958).

33. H. Heggestad, M. Millard, W. Wergin, R. Rufner, personal communications.

34. S. Mandy and A. B. Ackerman, J. Am. Med. Assoc. 213, 253 (1970).

35. C. S. White, J. H. Humm, E. D. Armstrong, N. P. V. Lundgren, Ariat. Med. 1, $439(1952)$.

36. G. W. Kling, unpublished data.

37. We thank the U.S. Office of Foreign Disaster Assistance, the U.S. embassy and consulate in Cameroon, the U.S. embassy in Paris, and the U.S. Agency for International Development Mission in Cameroon for support of our work. We appreciate the assistance and hospitality of the government and the people of Cameroon. This research was funded in part by the National Science Foundation, ORSTOM, and Centre National de la Recherche Scientifique. We appreciate the cooperation of Helimission pilots D. Yeoman and S. Bartalsky and members of the international scientific teams, as well as the help of P. Briggs, M. Golan-Bac, D Klick, R. Mariner, T. Presser, M. Pringle, R. Oremland, J. Timmins, L. White, and $S$. Wilson. The manuscript benefited from discussions with many colleagues especially I. Barnes, M. Goldhaber, C. Hearn, D. Livingstone, H. Northrop, and H. Sigurdsson.

\title{
Introduction of a Normal Human Chromosome 11 into a Wilms' Tumor Cell Line Controls Its Tumorigenic Expression
}

\author{
Bernard E. Weissman, Paul J. Saxon, Steve R. Pasquale, Gary R. Jones, \\ ANDREW G. Geiser, ERIC J. STANBRIDGE*
}

The development of Wilms' tumor, a pediatric nephroblastoma, has been associated with a deletion in the pl3 region of chromosome 11 . The structure and function or functions of this deleted genetic material are unknown. The role of this deletion in the process of malignant transformation was investigated by introducing a normal human chromosome 11 into a Wilms' tumor cell line by means of the microcell transfer technique. These variant cells, derived by microcell hybridization, expressed similar transformed traits in culture as the parental cell line. Furthermore, expression of several proto-oncogenes by the parental cells was unaffected by the introduction of this chromosome. However, the ability of these cells to form tumors in nude mice was completely suppressed. Transfer of other chromosomes, namely $X$ and 13, had no effect on the tumorigenicity of the Wilms' tumor cells. These studies provide support for the existence of genetic information on chromosome 11 which can control the malignant expression of Wilms' tumor cells.

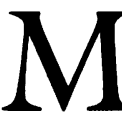

ALIGNANT TRANSFORMATION IN HUMAN CELLS APPEARS to be a multistep process $(1)$. One set of genes implicated in this progression is the dominantly acting transforming genes that were initially isolated from both avian and mammalian retroviruses (2). Cellular homologs of these retroviral transforming genes, termed proto-oncogenes, have been identified (3). Activated forms of these cellular genes, called oncogenes, have been shown to induce neoplastic transformation of rodent cells in culture in an apparently dominant fashion $(3,4)$. Transforming ability of these oncogenes may be associated with changes as subtle as a point mutation as well as partial deletions, translocations, or overexpression of the relevant proto-oncogene product. Up to now, more than 25 different cellular oncogenes have been isolated from various

B. E. Weissman, S. R. Pasquale, and G. R. Jones are in the Division of Hematology and Oncology, Childrens Hospital of Los Angeles, Los Angeles, CA 90027. P. J. Saxon, A. G. Geiser, and E. J. Stanbridge are in the Department of Molecular Genetics and Microbiology, University of California, Irvine, CA 92717. The present address of P. J. Saxon is Department of Pathology, Stanford University Medical Center, Stanford, CA 94305. The present address of G. R. Jones is Childrens Hospital Research Foundation, Cincinnati, OH 45229.

*To whom correspondence should be sent. 